\title{
Paramonacanthus oblongus, the correct name for the Indo-Pacific fish currently called $P$. japonicus, with a recommendation on the nomenclature of Stephanolepis cirrhifer (Tetraodontiformes, Monacanthidae)
}

\author{
Anthony C. Gill ${ }^{1}$ and J. Barry Hutchins ${ }^{2}$ \\ ${ }^{1}$ Department of Zoology, The Natural History Museum, London SW7 5BD, U.K. \\ ${ }^{2}$ Department of Aquatic Zoology, Western Australian Museum, \\ Francis Street, Perth, Western Australia 6000, Australia
}

\begin{abstract}
Members of the monacanthid genus Paramonacanthus Bleeker are small fishes (commonly known as leatherjackets and filefishes) that inhabit flat silty and sandy bottoms throughout the Indo-West Pacific. The genus was recently revised by Hutchins (1997), who recognised 11 species. Among these was $P$. japonicus (Tilesius, 1810) from the eastern Indian and West Pacific Oceans. However, we have since discovered that Tilesius's name is preoccupied and here correct the nomenclature of the species, as well as provide a new recommendation concerning Stephanolepis cirrhifer (Schlegel, 1850) from Japan and China.

Paramonacanthus japonicus was originally described (as Balistes japonicus) by Tilesius (1810) on the basis of a single specimen (presently lost) from Japan (see Hutchins, 1997: 29). However, Tilesius was unaware that Balistes japonicus had been used earlier by Walbaum (1792). Walbaum's description is very brief, but is nevertheless sufficient to make the name available:
\end{abstract}

\section{"Species adhuc dubiae}

20. BALSTES, japonicus, radiis pinnae dorsalis 3 v. 4 . $W$. Balistes monoceros. Einhörniche Hoornvisch. Houttuyni. Act. Harl. XX. P. 2. n. 33. D. 3-4. P. 13. V ... A... C. 14. Longitudo 6 unciarum. Color subfuscus vel cinereus. Anteriorum radiorum unus exit in longum filum."

This indicates that Walbaum's description was based on the earlier account of Houttuyn (1782) under the name Balistes monoceros. Houttuyn's description (p. 345) is reproduced here:

“34. (stated as 33 by Walbaum) BALISTES MONOCEROS. Eenhoornige Hoornvisch

Van deezen Visch, die in de beide Indien huisvest, heb ik een schoon groot Exemplaar van Japan ontvangen. Het is meer dan zes Duimen lang, en overtrest dus in groote de Afbeelding van een zodanigen, welke ik volgens een Voorwerp, uit het Kabinet van den Wel Ed. Heer W. vAN DER MEULEN, nu ruim zestien Jaaren geleeden, aan't licht bragt (h). In Kleur niet alleen, die bruin is of graauw, mar ook in de telling der Vinstraalen, komt het daar mede vry wel overeen: want ik vind in de Rugvin en Aarsvin, beiden, drie of vierendertig, in de Borstvinnen dertien, en in de Staartvin veertien Straalen. Het byzonderste is, dat een der voorsten van de Rugvin uitloopt in een langen Draad."

Our translation of Houttuyn's description is as follows:

"These fish that live in both Indies I have received a good example from Japan. It is more than 6 thumbs long. I compared it with a figure of something similar which was brought to light 16 years ago from the cabinet of $\mathrm{Mr} \mathrm{W}$. van der Meulen. It compares well not only in colour which is dull brown but also in the fin rays: the back fin and anal fin both three or four and thirty (= thirty-three or thirty-four), the breast fin thirteen and the tail fin fourteen rays. The most outstanding feature is the first of the back fin which runs in one long thread."

Walbaum's description deviates from Houttuyn's in several features, most notably in recording only 3-4 dorsal rays and not providing a count for the anal fin. We surmise that this may have resulted from confusion over his translation of Houttuyn's phrase: "want ik vind in de Rugvin en Aarsvin, beiden, drie of vierendertig" (see above). Apparently it was also enough to cause subsequent workers to ignore Walbaum's name.

Houttuyn's description appears to have been based on a species belonging to the Monacanthidae. It was, as stated in the introduction to Houttuyn's paper, collected by Carel ( $=$ Carl) Thunberg in Japan and provided to Houttuyn through the auspices of J.C.M. Radermacher. The meristic values-allowing for a count of 14 caudal-fin rays which is two more than is typical for the familyand elongate, threadlike filament in the dorsal fin suggest that it was based on Stephanolepis cirrhifer (Schlegel, 1850). There are no balistids in the Japanese region that possess an elongate ray anteriorly in the soft dorsal fin and the only other Japanese monacanthid so adorned is Pervagor nigrolineatus (Herre), a species that occurs in the 
Ryukyu Islands (Matsuura and Sunobe, 1990) and possesses only 25-30 anal-fin rays (Hutchins, 1986). Therefore Balistes japonicus Walbaum, 1792, is most likely a senior synonym of the species originally described by Schlegel (1850) as Monacanthus cirrhifer. However, as mentioned above, we are unaware of the use of Walbaum's name for this or any other species since it was first described. Conversely, Stephanolepis cirrhifer has been universally applied to this species in recent literature (see below), and we thus advocate its continued use.

Article 23.9 of the International Code of Zoological Nomenclature requires that the adoption of a younger name over a disused older one must be accompanied by evidence that the younger name has been used as the presumed valid name in at least 25 works, published by at least 10 authors in the immediately preceeding 50 years, and spanning at least 10 years. Therefore, the following works are submitted here to fulfil this requirement: Abe (1986), Burgess and Axelrod (1972), Chyung (1961, 1977), FAO (1992), Kamohara (1967), Konishi (1995), Masuda and Allen (1987), Masuda et al. (1975, 1984); Masuda and Kobayashi (1994), Matsuura (1979), Murofushi and Yosida (1979), Nakabo (1993), Okada (1955), Patzner and Moosleitner (1999), Randall et al. (1997), Safran (1990), Safran and Omori (1990), Shen (1994), Shiino (1972), Sokolovskaya et al. (1998), Taguchi (1985), Tyler (1980), and Vasil'yev (1980).

According to Article 57.2 of the International Code of Zoological Nomenclature, Balistes japonicus Tilesius (1810) is a junior primary homonym of Balistes japonicus Walbaum (1792), and is thus permanently invalid. Hutchins (1997) showed that the next available name for Tilesius's species is Monacanthus oblongus Schlegel (1850). Hutchins noted that Schlegel's description is composite, being based on specimens of the present species and Thamnaconus septentrionalis (Günther); he also noted that the "type illustration" was based on a male of the present species. However, he was unaware that Boeseman (1947: 209) had also showed that Schlegel's description was a combination of two species, and had in turn designated a lectotype for the species (Boeseman's description of the lectotype [RMNH 4133b] clearly identifies it with a male specimen of the species called Paramonacanthus japonicus by Hutchins, 1997). The correct name for this species thus becomes Paramonacanthus oblongus (Schlegel, 1850).

\section{ACKNOWLEDGEMENTS}

We thank Anne Nevin (Western Australian Museum) for translating portions of Houttuyn's 1782 paper.

\section{REFERENCES}

Abe, T. (1986). Keys to the Japanese Fishes Fully Illustrated in Colors. Twelfth revised edition. Hokuryukan, Tokyo.

Boeseman, M. (1947). Revision of the fishes collected by Burger and Von Siebold in Japan. E.J. Brill, Leiden.

Burgess, W.E. and Axelrod, H.R. (1972). Pacific marine fishes. Book 1. TFH Publications, Neptune City.

Chyung, M.-K. (1961). Illustrated Encyclopedia. The Fauna of Korea (2), Fishes. Ministry of Education, Seoul.

Chyung, M.-K. (1977). The Fishes of Korea. Il Ji Sa, Seoul.

FAO (Food and Agriculture Organization) (1992). Fishery statistics: catches and landings, volume 74. FAO Fisheries Series 43.

Houttuyn, M. (1782). Beschryving ven eenige Japanse visschen, en andere zee-schepzelen. Verhandelingen Uitgegeeven door de Hollandsche Maatschappye der Weetenschappen, te Harlem 20(2): 311-350.

Hutchins, J.B. (1986). Review of the monacanthid fish genus Pervagor, with descriptions of two new species. Indo-Pacific Fishes 12: 1-35.

Hutchins, J.B. (1997). Review of the monacanthid fish genus Paramonacanthus, with descriptions of three new species. Records of the Western Australian Museum, Supplement 54: 1-57.

Kamohara, T. (1967). Fishes of Japan in Color. Hoikusha Publishing, Osaka.

Konishi, H. (1995). Fishes - New Color Guide for sportsfishermen. Weekly Sunday Fishing, Osaka.

Masuda, H. and Allen, G.R. (1987). Sea fishes of the world (Indo-Pacific region). Yama-Kei Publishers, Tokyo.

Masuda, H., Amaoka, K., Araga, C., Uyeno, T. and Yoshino, T. (1984). The fishes of the Japanese Archipelago. Vol. 1-2. Tokai University Press, Tokyo.

Masuda, H., Araga, C., and Yoshino, T. (1975). Coastal fishes of Southern Japan. Tokai University Press, Tokyo, Japan.

Masuda, H. and Kobayashi, Y. (1994). Grand Atlas of fish life modes. Color variation in Japanese Fish. Tokai University Press, Tokyo.

Matsuura, K. (1979). Phylogeny of the superfamily Balistoidea (Pisces: Tetraodontiformes). Memoirs of the Faculty of Fisheries, Hokkaido University 26(1/2): 49169.

Matsurra, K. and Sunobe, T. (1990). First record of the filefish, Pervagor nigrolineatus, from Japan. Japanese Journal of Ichthyology 37(2): 198-199.

Murofushi, M. and Yosida, T.H. (1979). Cytogenetical studies on fishes, I. Karyotypes of four filefishes. Japanese Journal of Genetics 54(3): 191-195.

Nakabo, T. (ed.) (1993). Fishes of Japan with Pictorial Keys to Species. Tokai University Press, Tokyo.

Okada, Y. (1955). Fishes of Japan. Illustrations and descriptions of Fishes of Japan. Maruzen, Tokyo.

Patzner, R.A. and Moosleitner, H. (1999). Meerwasser atlas Band 6: non-Perciformes. Mergus, Melle.

Randall, J.E., Ida, H., Kato, K., Pyle, R.L. and Earle, J.L. (1997). Annotated checklist of inshore fishes of the Ogasawara Islands. National Science Museum Monograph(11): 1-74.

Safran, P. (1990). Drifting seaweed and associated 
ichthyofauna: floating nursery in Tohoku waters. $L a$ mer 28(4):225-239.

Safran, P. and Omori, M. (1990). Some ecological observations on fishes associated with drifting seaweed off Tohoku coast, Japanese Marine Biology 105: 395-402.

Schlegel, H. (1850). Pisces. In Fauna Japonica. Von Siebold, P.F (ed), Leiden.

Shen, S.C. (ed.) (1994). Fishes of Taiwan. Department of Zoology, National Taiwan University, Taipei.

Shiino, S.M. (1972). List of English names for Japanese fishes with proposition of new names. Science Report of Shima Marineland no. 1: 1-210.

Sokolovskaya, T.G., Sokolovskii, A.S., and Sobolevskii, E.I. (1998). A list of fishes of Peter the Great Bay (the Sea of Japan). Japanese Journal of Ichthyology 38(1): 111.

Taguchi, T. (1985). Fishes of Izu Islands and Bonin Islands. Nippon Television, Tokyo.
Tilesius, W.G. (1810). Description de quelques poissons observés pendant son voyage autor du monde. Mémoires de la Société Impériale des Naturalistes de Moscou (1809) 2: 212-249.

Tyler, J.C. (1980). Osteology, phylogeny, and higher classification of the fishes of the Order Plectognathi (Tetraodontiformes). US Department of Commerce, NOAA Technical Report NMFS Circular 434: 1-422.

Vasil'yev, V.P. (1980). Chromosome numbers in fish-like vertebrates and fish. Japanese Journal of Ichthyology 20(3): 1-38.

Walbaum, J.J. (1792). Petri Artedi Sueci Genera piscium. In quibus systema totum ichthyologiae proponitur cum classibus, ordinibus, generum characteribus, specierum differentiis, observationibus plurimis. Redactis speciebus 242 ad genera 52. Ichthyologiae, pars iii. Artedi Piscium Pt. 3: 1-723.

Manuscript received 24 May 2000; accepted 2 July 2001. 


\section{Guide to Authors}

\section{Subject Matter:}

Reviews, observations and results of research into all branches of natural science and human studies will be considered for publication. However. emphasis is placed on studies pertaining to Western Australia. Longer papers will be considered for publication as a Supplement to the Records of the Western Australian Museum. Short communications should not normally exceed three typed pages and this category of paper is intended to accommodate observations, results or new records of significance, that otherwise might not get into the literature, or for which there is a particular urgency for publication. All material must be original and not have been published elsewhere.

\section{Presentation:}

Authors are advised to follow the layout and style in the most recent issue of the Records of the Westem Austrulian Museum including headings, tables, illustrations and references.

The title should be concise. informative and contain key words necessary for retrieval by modern searching techniques. An abridged title (not exceeding 50 letter spaces) should be included for use as a running head.

An abstract must be given in full length papers but not short communications, summarizing the scope of the work and principal findings. It should normally not exceed $2 \%$ of the paper and should be suitable for reprinting in reference periodicals.

The International System of units should be used.

Numbers should be spelled out from one to nine in descriptive text; figures used for 10 or more. For associated groups, figures should be used consistently, e.g. 5 to 10 . not five to 10 .

Spelling should follow the Concise Oxford Dictionary

Systematic papers must conform with the International Codes of Botanical and Zoological Nomenclature and, as far as possible, with their recommendations.

Synonymies should be given in the short form (taxon, author, date, page) and the full reference cited at the end of the paper. All citations, including those associated with scientific names, must be included in the references.

\section{Manuscripts:}

The originat and two copies of manuscripts and figures should be submitted to the Editors, $\%$ Publications Department. Western Australian Museum, Francis Street, Perth, Western Australia 6000. They must be in double-spaced typescript on A4 sheets. All margins should be at least $30 \mathrm{~mm}$ wide. Tables plus heading and legends to illustrations should be typed on separate pages. The desired position for insertion of tables and illustrations in the text should be indicated in pencil. Tables should be numbered consecutively, have headings which make them understandable without reference to the text, and be referred to in the text.

High quality illustrations are required to size $(16.8 \mathrm{~cm} \times 25.2 \mathrm{~cm})$ or no larger than $32 \mathrm{~cm} \times 40$ $\mathrm{cm}$ with sans serif lettering suitable for reduction to size. Photographs must be good quality black and white prints, not exceeding $16.8 \mathrm{~cm} \times 25.2 \mathrm{~cm}$. Scale must be indicated on illustrations. All maps. line drawings, photographs and graphs, should be numbered in sequence and referred to as Figure/s in the text and captions. Each must have a brief, fully explanatory caption. On acceptance a computer disk containing all corrections should be sent with amended manuscript. The disk should be marked with program (e.g. Word, WordPerfect, etc).

In papers dealing with historical subjects references may be cited as footnotes. In all other papers references must be cited in the text by author and date and all must be listed alphabetically at the end of the paper. The names of journals are to be given in full.

\section{Processing:}

Papers and short communications are reviewed by at least two referees and acceptance or rejection is then decided by the editors.

The senior author is sent one set of page proofs which must be returned promptly.

The senior author will receive fifty free offprints of the paper. Additional offprints can be ordered at page proof stage. 


\section{Records of the Western Australian Museum Volume 21 Part 12002}

\section{CONTENTS}

A.M. Pinder and S.A. Halse

Two new species of Ainudrilus (Clitellata: Tubificidae) from southwestern Australia, with notes on Ainudrilus nharna Pinder and Brinkhurst

D.J. Kitchener and A. Suyanto

Morphological variation in Miniopterus pusillus and $M$. australis (sensu Hill 1992) in southeastern Asia, New Guinea and Australia

\section{M.S. Harvey}

A new species of Austrarchaea (Araneae: Archaeidae) from Western Australia

K.S.W. Campbell, R.E. Barwick, B.D.E. Chatterton and T.R. Smithson A new Middle Devonian dipnoan from Morocco: structure and histology of the dental plates

P. Kott

Culeolus herdmani Sluiter, 1904 (Ascidiacea, Tunicata) from the northwestern Australian continental slope with an overview of the genus

A.J. Bruce

Leander manningi, a new palaemonine shrimp from Western Australia (Crustacea, Decapoda, Palaemonidae), with a review of the Indo-West Pacific species of the genus Leander E. Desmarest, 1849

J.H. Bradbury

Melitid amphipods of Barrow Island, Western Australia

Part II - recent discoveries

\section{SHORT COMMUNICATIONS}

M.S. Harvey and E.S. Volschenk

A forgotten scorpion: the identity of Buthus flavicruris Rainbow, 1896

(Scorpiones), with notes on Urodacus manicatus (Thorell)

A.C. Gill and J.B. Hutchins

Paramonacanthus oblongus, the correct name for the Indo-Pacific fish currently called $P$. japonicus, with a recommendation on the nomenclature of Stephanolepis cirrhifer (Tetraodontiformes, Monacanthidae)

\section{Dates of Publication}

Records of the Western Australian Museum

Volume 20, Part 1

Volume 20, Part 2

Volume 20, Part 3

Volume 20, Part 4
22 August 2000

21 March 2001

20 December 2001

22 April 2002 